\title{
POSZUKIWANIE DETERMINANTÓW JAKOŚCI PROGRAMU JAKO ELEMENTÓW STRATEGII W MEDIACH PUBLICZNYCH. MODEL TRÓJKĄTA SIŁ JAKOŚCI
}

\author{
Abstract \\ EXPLORING DETERMINANTS OF PROGRAM QUALITY IN PUBLIC MEDIA \\ AS ELEMENTS OF STRATEGY. THE QUALITY POWER TRIANGLE MODEL
}

The purpose of the article is to present the importance, the function of program quality in public media, as well as the influence of "quality" on the creation of strategy and success of stations. The first part of the paper is devoted to the analysis of the literature on the subject, thanks to which the significant meaning of quality in this measure was shown. The second part presents the application of the media quality forces triangle model to the research. Consequently, the analysis of the results of the surveys conducted with this method in 2015 and 2021 is presented. This research shows the differential influence of the factors that were introduced in the survey on the basis of quality descriptors. The respondents came from two groups: media professionals and students. In their opinion, qualified staff and station creators have the greatest influence on the two-seeing quality, in second place is the knowledge of the audience market, and in third place were the factors that create the station's financing. Moreover, the results of the study show interesting differences in opinions among the surveyed groups over several years.

Keywords: quality in media, content, determinants of quality in media, broadcaster's strategy

JEL: L82

\section{Wprowadzenie. Podstawy teoretyczne i wyjaśnienie pojęć}

Arystoteles pojęcie jakości przeciwstawiał ilości, wyrażając zawarte w nim specyficzne przyporządkowanie materii do formy. Jego zaś mistrz i nauczyciel - Platon rozumiał jakość jako „pewien stopień doskonałości”. W powszechnym przekonaniu 
„jakość” to gwarancja dobrego wykonania, lepszego gatunku, wartość sama w sobie, w przeciwieństwie do rzeczy czy działań niewartościowych, byle jakich. Zatem, opierając się na platońskiej inspiracji wychodzącej od pojęcia bytu idealnego, można sformułować tezę: posługiwanie się kategorią "jakości” w zarządzaniu stanowi działanie mające na celu osiąganie doskonałości, planu idealnego, założeń projektowych, to proces ciągłego doskonalenia, a według japońskiej filozofii kaizen - to stała maksymalizacja efektów przez dobór odpowiednich metod.

Na potrzeby artykułu jakość w mediach publicznych ${ }^{1}$ jest wypadkową korelacji trzech grup aspektów: kreacji i wiedzy, finansowania, znajomości potrzeb odbiorców. Analiza determinantów jakości zostanie tu przeprowadzona z wykorzystaniem modelu trójkąta sił jakości (rycina 1). Składa się on z trzech elementów: belki o charakterze endogennym - jako umiejętności kadry, belki o cechach mieszanych opisującej finansowanie zawartości programowej, i belki egzogenicznej - opisującej znajomość rynku odbiorcy. Pozwoli to na analizę wyników ankiety przeprowadzonej na podstawie tego modelu.

Celem niniejszego artykułu jest wskazanie kluczowej (strategicznej) roli, jaką odgrywa jakość w programach mediów publicznych, i wskazanie czynników, które ją kształtują i w jakim stopniu. W artykule poddana jest weryfikacji myśl, że jakość treści jest istotnym czynnikiem wpływającym na sprawność i skuteczność działania organizacji medialnych. Nadawcy, formułując swoje strategie, często odwołują się do jakości programów. W niniejszym artykule przeprowadzono wywód oparty na dwuetapowej hipotezie. Pierwszy zakłada, że jakość programu w mediach publicznych powinna zajmować kluczową pozycję przy formowaniu strategii nadawcy, jako że stanowi o jej sukcesie. Drugi etap zagłębia się w samo zagadnienie jakości i zakłada, że jest ona wypadkową wielu czynników nierównomiernie wpływających na jej powstawanie. Artykuł został oparty na źródłach wtórnych i pierwotnych.

Punktem odniesienia tego tekstu są zasady prakseologii Tadeusza Kotarbińskiego (2019), który w Traktacie o dobrej robocie definiuje organizację jako „pewien rodzaj całości, ze względu na stosunek do niej jej własnych elementów, a mianowicie taką całość, której wszystkie składniki współprzyczyniają się do powodzenia całości” (Kotarbiński, 2019, za: Sułkowski, 2012, s. 47). Stąd Sułkowski wywodzi myśl, że organizacja jest „celowym systemem w działaniu” (2012, s. 47). Cechą, warunkiem sine qua non, jest jej sprawność, tak jak ją pojmował Kotarbiński: „sprawnym nazywamy wszelkie takie działanie, które jest zarazem celowe, energiczne i ekonomiczne" (Kotarbiński, 1970, s. 249). A zatem celowość działania u Kotarbińskiego jest terminem nieodległym od skuteczności, ponieważ „żąda by działanie osiągało cel, dla którego zostało przedsięwzięte” (1970, s. 250). „Za sprawne uważać należy tylko takie działanie, które osiąga cel dzięki swej racjonalnej do tego celu dostosowanej strukturze” (Kotarbiński, 1970, s. 250). „Cel może być osiągnięty z większym lub mniejszym przybliżeniem, wytwór może mniej lub bardziej odbiegać od

1 Jest to 19 spółek Skarbu Państwa. 
wzorca, wedle którego miał być wykonany, słowem, to, co się miało zrobić, można zrobić bardziej lub mniej dokładnie. (...) Zasoby pieniężne (...) są częstokroć jedyną właściwą, dla danej sprawy postacią energicznego zachowania się" (Kotarbiński, 1970, s. 251). Kotarbiński pod pojęciem energiczności rozumie „zdobywanie się na wszelki wkład niezbędny”, a z kolei ekonomiczność „jest pilnowaniem, by wydatkować zasobów nie więcej niż to jest niezbędne ze względu na dany cel” (1970, s. 251, 252). Podobne akcenty znajdujemy w opracowaniu Adama Hamrola i Władysława Mantury (2002, s. 11), gdy skutki sprawcze powiązane są z osiąganiem celów jakościowych. W takim kontekście rozważane są kwestie jakości programu. Również Ruth Towse zauważa:

Bez standardów doskonałości, których rynek raczej nie dostarczy przy podaży opartej na motywach komercyjnych, konsumenci nie mają możliwości nauczyć się jakiej jakości dóbr (dzieł sztuki lub usług nadawczych) mogliby się domagać i przez to nie mogą podejmować świadomych decyzji, niezbędnych dla ich suwerenności konsumenckiej. Pozornie argument ten zbliżony jest do paternalistycznego wydźwięku koncepcji dóbr społecznie pożądanych, ale w istocie jest on odmienny, koncentruje się na zjawisku niedostatku informacji na temat działania rynków - niedostatku mogącego prowadzić do zawodności rynku w obszarze dostarczanej jakości. Informowanie o jakości nie jest równoznaczne z tym, co jest dobre dla ludzi. Dobra informacyjne, zwłaszcza wiedza, są dobrami publicznymi (Towse, 2011, s. 490).

I, jak dalej argumentuje autorka, wpływa to na jakość oferty - polityka nadawców publicznych powinna pozostawać niezależna od doktrynalnej chęci interwencjonizmu.

Podobnie Karol Jakubowicz, szukając uzasadnienia dla działania mediów publicznych w warunkach wolnego rynku, wskazuje na ich zadania, które można ująć w czterech kategoriach (2013, s. 183):

(1) informacji i kontroli władzy; (2) utworzenia forum dla debaty publicznej; (3) stwarzania możliwości dla prezentacji i autoprezentacji różnych grup społecznych; (4) funkcji partycypacyjnej jako szczególnego wkładu mediów w budowę demokracji, a tym samym umacnianie relacji ze społeczeństwem. Określone przez Jakubowicza zagadnienia współtworzą zatem sferę publiczną, rozumianą tu jako umowny obszar otwartej dyskusji adresowanej do ogółu społeczeństwa lub jego grup w zakresie wymiany informacji. To podstawowa funkcja mediów, zwłaszcza publicznych. Nawiązując do punktu 1, warto przywołać w tym miejscu myśl Bogusława Nierenberga: „W przypadku mediów publicznych ważne jest, by podstawy ich ekonomicznej egzystencji nie podlegały politycznym koniunkturom czy naciskom" (2011, s. 88).

W takim ujęciu zostaje nakreślone spektrum spraw, które powinny mieć istotny wpływ na kształtowanie jakości programu mediów publicznych. Wymienione przez Jakubowicza aspekty rzecz jasna nie wyczerpują zakresu zagadnień jakościowych treści w mediach. Pozostałą kwestią jest produkcja treści o charakterze edukacyjnym, rozrywkowym i artystycznym. Zatem pod uwagę powinny być brane 
dwa odmienne kryteria - prawdy (obiektywizmu) i piękna (estetyczne) (por. Sułkowski, 2012, s. 65-67). W innym miejscu Jakubowicz zauważa, że

(...) obowiązki mediów publicznych mają charakter jakościowy, wszelkie przepisy [w tym zakresie] zaś mają charakter negatywny (czego nie wolno robić), w najlepszym przypadku ilościowy (np. ile czasu antenowego poświęcić na dany gatunek), nie mogą natomiast skutecznie wpłynąć na to, jak ten program ma być tworzony, czyli właśnie na jego jakość (Jakubowicz, 2007, s. 54).

W dalszej części zauważa szczególną rolę dużych nadawców, zwłaszcza publicznych, i potrzebę kształcenia takiej kadry, która zdolna będzie do produkowania programów „o cechach i wymaganiach” (Jakubowicz, 2007, s. 54) zgodnych z kryteriami i standardami mediów publicznych. Jakość audycji w mediach publicznych, zdaniem Jakubowicza, staje się zatem strukturalnym punktem odniesienia. Media publiczne mają obowiązek dostarczania treści ambitnych, zgodnych $\mathrm{z}$ tradycją, historią i szeroko rozumianą kulturą, zachowując bezpieczny dystans od zjawisk popkulturowych czy sprzyjających homogenizacji kulturowej. W tej mierze istotne jest uprawianie gatunków artystycznych kojarzonych ze sztuką wysoką, na przykład w telewizji film artystyczny, dokument, teatr, w radiu gatunki udramatyzowane, reportaż (Wolny-Zmorzyński i in., 2006). Produkcja i emitowanie wartościowych gatunków artystycznych są zgodne z podnoszeniem jakości. Treść w mediach publicznych powinna być przeciwieństwem zapotrzebowania na treści medialne generowane w ramach inercyjnego społeczeństwa kontentowego (Rogowski, 2020, s. 23). Rynek i wolność gospodarcza „podcinają ideowy fundament działania mediów publicznych (...), kwestionując zasadność istnienia instytucji publicznych w tej sferze" (Jakubowicz, 2013, s. 180), i - jak twierdzi Zygmunt Bauman - „kultura płynnej ponowoczesności (w tym media publiczne) nie ma ludu do oświecania i uszlachetniania, ma natomiast klientów do uwodzenia” (za: Jakubowicz, 2013, s. 180).

Wobec powyższego tym bardziej kluczowe staje się określenie jakości przekazów medialnych. Należy zakładać, że odbiorcy chcą otrzymywać treści ciekawe i odpowiadające potrzebom, a także takie, które będą kształtować ich potrzeby i oczekiwania. Zadaniem organizacji medialnych, zwłaszcza publicznych, jest natomiast ciągłe doskonalenie treści, wynikające z zasad zarządzania jakością. Oferta mediów i reaktywne oczekiwania odbiorców powinny przypominać zaplatanie warkocza. Żadna ze stron samodzielnie tego nie zrobi. W polskich warunkach szczególną rolę w kształtowaniu jakości w mediach publicznych odgrywa ustawa z 29 grudnia 1992 roku o radiofonii i telewizji, w szczególności art. 1.1 wyznaczający zadania radiofonii i telewizji. Istotny jest zwłaszcza art. $21^{2}$ ustawy, dotyczący zadań misji mediów publicznych. Artykuł ten, w którym w ustawie po raz pierwszy pada słowo

2 W rozwinięciu art. 21.1, kolejne ust. 1a do 2 szczegółowo opisują cele, sposoby i zadania realizacji misji. 
jakość ${ }^{3}$, to także katalog zadań i powinności w odniesieniu do programów i usług, wraz z ich sposobem finansowania (Ustawa o radiofonii i telewizji, 1992). Na mediach publicznych spoczywa obowiązek dotrzymywania wysokich standardów jakościowych w powiązaniu z podmiotową rolą odbiorców rozumianych jako społeczeństwo obywatelskie. $\mathrm{W}$ takim rozumieniu media publiczne są konieczne do budowania postaw obywatelskich. Dlatego też państwo przeznacza znaczne środki na utrzymanie tych mediów (abonament, dotacje). Ważną pozycję regulatora ma Krajowa Rada Radiofonii i Telewizji, gdyż w praktyce zarówno nadzoruje jakość $\mathrm{w}$ mediach przez ustawę i wydawane rozporządzenia, jak i przyznaje kwoty $\mathrm{z}$ abonamentu na finansowanie wspomnianych zadań w ramach art. 21 ust. 1 . W związku z tym w celu koniecznego doprecyzowania zakresu zadań misji w 2018 roku wprowadzono w art. 21a ust. 1 długo postulowane karty powinności (Nowelizacja ustawy o radiofonii i telewizji, 2018) ${ }^{4}$ jako parastrategiczne plany pięcioletnie (Tazowski, 2019, s. 84-85).

Jak wspomniano, osiąganie celów jakościowych jest powiązane ze skutecznym zarządzaniem firmą (Hamrol, Mantura, 2002). Powinno być również powiązane ze strategią uwzględniającą rozwój i skuteczną komunikację z otoczeniem.

Strategii nie można określić wyłącznie z perspektywy konkurencji lub presji wywieranej z zewnątrz. Jakkolwiek celem strategii jest podtrzymanie lub poprawa pozycji konkurencyjnej przedsiębiorstwa (na przykład pozycji lidera), musi ona także zapewnić realizację zobowiązań zawartych w deklaracji misji (Cardona, Rey, 2013, s. 115).

Tym samym uwzględnianie, także w mediach publicznych, zagadnień jakości staje się immanentnym elementem strategii i tożsamości. Jeśli iść tym tropem, warto przytoczyć klasyfikację czynników składających się na tożsamość jako elementów strategii. Zarówno w publicznym radiu regionalnym, jak i w innych mediach będą to: „specjalizacja w dziedzinie wytwarzanych radiowych produktów i usług, jakość wyrobów, obsługa wybranych segmentów rynku i utrwalanie wizerunku" (Kosiorowski, 2014, s. 74). Per analogiam w strategii Telewizji Polsat znajdujemy deklarację:

Naszą misją jest tworzenie i dostarczanie najatrakcyjniejszych treści telewizyjnych (...), świadczenie wysokiej jakości usług zintegrowanych ${ }^{5}$, odpowiadających na zmieniające się potrzeby naszych klientów oraz utrzymanie najwyższego poziomu ich satysfakcji (Cyfrowy Polsat, 2020).

3 Słowo „jakość” w ustawie użyte jest tylko dwukrotnie, po raz drugi - w odniesieniu do zadań Rad Programowych w mediach publicznych - w art. 28a.

4 Ustawa z dnia 20 lipca 2018 r. o zmianie ustawy o radiofonii i telewizji oraz ustawy o opłatach abonamentowych. Dz.U. 2018 poz. 1717.

5 W skrócie: IntServ - jeden z mechanizmów zapewniających jakość usług (ang. Quality of Service). 
Idąc dalej w tym kierunku, zauważono, że w myśleniu o strategiach firm pojawia się nawet konfrontacyjny charakter frazeologii, spotykamy takie określenia, jak „walka przez jakość” (Sudoł, 1992), która jest konieczna do skutecznego zajęcia wysokiego miejsca na rynku, w tym wypadku przez produkty stacji.

\section{Metodologia}

W niniejszym opracowaniu kluczowa jest koncepcja trójkąta sił jakości w mediach publicznych, pozwalająca zarówno określać determinanty i kształtowanie jakości, jak przyporządkować i badać czynniki, które wpływają na stymulowanie jakości przekazów audiowizualnych.

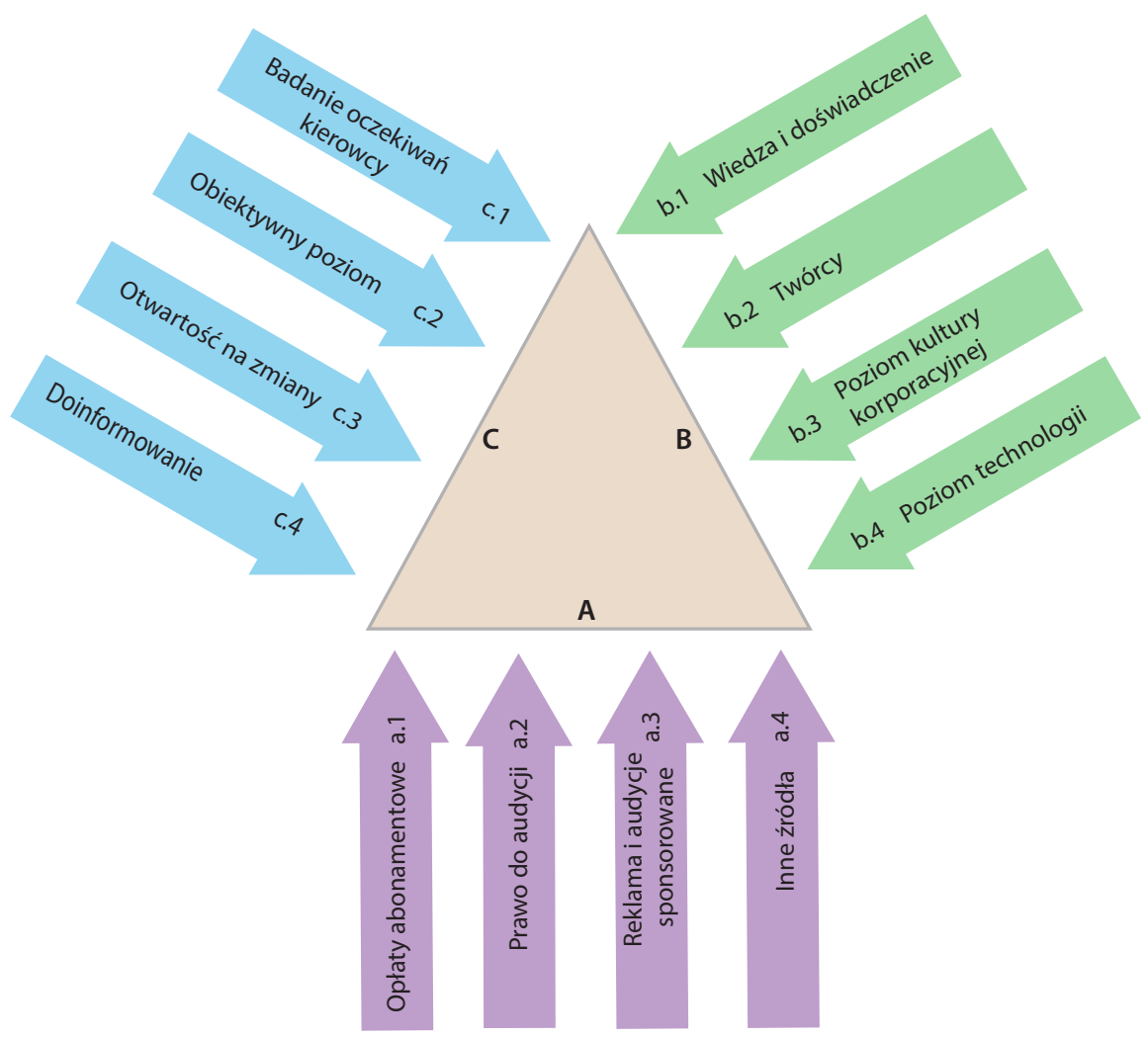

Rycina 1. Trójkąt sił jakości w mediach publicznych i podstawowe grupy czynników

Źródło: opracowanie własne autora. 
Model (rycina 1) jest inspirowany trójkątem sił medialnych Bogusława Nierenberga, posiadającym determinanty: władza państwowa, reklamodawcy, odbiorcy mediów (2011, s. 154-156). Na potrzeby badań zaprojektowano odrębny schemat dotyczący „sił jakości w mediach publicznych”, a w konsekwencji opracowano ankietę dedykowaną kształtowaniu sił jakości.

W trakcie badania przyjęto założenie, że jakość programu w mediach publicznych jest kluczowym czynnikiem determinującym sukces strategiczny nadawcy. Stwierdzenie to dotyczy założeń badawczych w latach $2015^{6}$ i 2021 . Dalej przedstawiono model trójkąta medialnych sił jakości z pogrupowaniem na zespoły czynników A, B, C (rycina 1). W skonstruowaniu formularza ankiety badawczej pomocna była metoda teorii ugruntowanej (Glaser, Strauss, 2009). Na potrzeby badania w 2015 roku przyjęto, że należy posłużyć się merytoryczną i fachową wiedzą respondentów, których wyłoniono w dwóch grupach podstawowych: (a) doświadczeni pracownicy oraz współpracownicy mediów publicznych i innych stacji; (b) studenci dziennikarstwa. Tym samym zawodowcy, eksperci stanowili 80 osób $(47,6 \%)$, a studenci dziennikarstwa bez szczególnej praktyki, specjaliści in spe - 88 osób $(53,4 \%)$. Założenia te zostały powtórzone w drugim badaniu, z 2021 roku, kiedy za pomocą formularza Google wypełniono 194 ankiety w proporcji: profesjonaliści $48,9 \%$, i studenci $-51,1 \%$. W rezultacie powstało badanie porównawcze $\mathrm{z}$ obu lat.

Celem obydwu badań ankietowych było uzyskanie obrazu rozkładu sił odzwierciedlającego działanie różnych czynników warunkujących powstawanie programu, jakim powinni charakteryzować się nadawcy publiczni, a którzy - jak wspomniano we wstępie artykułu - stanowią istotny punkt odniesienia, zgodnie z art. 21 ust. 1 Ustawy o radiofonii i telewizji (1992):

(...) publiczna radiofonia i tv, realizuje misję publiczną, oferując, na zasadach określonych w ustawie, całemu społeczeństwu i poszczególnym jego częściom, zróżnicowane programy i inne usługi w zakresie informacji, publicystyki, kultury, rozrywki, edukacji, i sportu, cechujące się pluralizmem, bezstronnością, wyważeniem i niezależnością oraz innowacyjnością, wysoką jakością i integralnością przekazu?

We wzmiankowanym artykule ustawy pewne cechy, według ustawodawcy istotne dla właściwej realizacji zadań przez media publiczne, zostały wymienione w sposób enumeratywny. Słowo jakość pada tylko raz i ma ogólnikowe znaczenie. Nie nadano tej kategorii cech wyróżniających. Badanie stawia sobie zatem za cel uzupełnienie w tym zakresie i ustalenie, jakie czynniki i w jakim stopniu wpływają na uzyskiwanie w mediach publicznych możliwie najwyższej jakości kontentu.

Przedstawiony model trójkąta (rycina 1) ma charakter schematyczny i zmierza w kierunku sparametryzowania opinii respondentów na temat determinantów jakości programu w mediach publicznych. Wyodrębniono trzy podstawowe grupy

6 Badania z 2015 r. zamieszczono w dysertacji doktorskiej autora z 2016 r.

7 Ustawa o radiofonii i telewizji (1992) w art. 21 ust 1 szczegółowo wymienia zadania i cechy programu misyjnego. 
czynników: belka A - finansowanie; belka B - kwalifikacje pracowników; belka C znajomość rynku odbiorców.

Do ankiety załączono instrukcję jej wypełniania, z następującymi wskazówkami:

Uwagi ogólne. Wypełniających ankietę poproszono o wpisywanie wartości punktowych. W ankiecie można było wpisywać jedynie liczby całkowite w przedziale od minimum 1 do maksimum 5. Ankieta zawierała specyfikację czynników $\mathrm{w}$ rozszerzonym opisie. W niniejszym artykule opis ograniczony jest do podstawowego znaczenia deskryptorów w każdej grupie o numerach 1-4:

A. Finansowanie mediów publicznych - jest zespołem czynników, które mają wpływ na jakość powstającego/emitowanego kontentu. Wśród źródeł finansowania, o różnej skali i znaczeniu, wymieniamy:

A.1) opłaty abonamentowe;

A.2) $\mathrm{z}$ obrotu prawami do audycji;

A.3) z reklam i audycji;

A.4) z innych źródeł, mogą to być: dotacje, programy operacyjne, dzierżawy.

B. Kwalifikacje pracowników mediów stanowią zespół czynników mających, w różnym stopniu, wpływ na jakość programu/kontentu w mediach publicznych (tzw. know-how); są to:

B.1) wiedza, gust i doświadczenie pionu redakcyjnego stacji (redaktorzy zamawiający), napływ nowej kadry (relacja mistrz-uczeń);

B.2) twórcy - poziom i smak artystyczny, talent, pomysły. Stały dopływ nowych scenariuszy i projektów;

B.3) poziom kultury korporacyjnej kadry stacji, menedżerów, specjalistów w zakresie ekonomii, prawa, administracji - rodzaj tradycji, obranej specyfiki programowej, model współpracy z partnerami zewnętrznymi;

B.4) poziom technologii, innowacyjność, HD, efekty specjalne, umiejętność właściwego wykorzystania w procesie tworzenia atrakcyjnego kontentu.

C. Znajomość rynku odbiorcy - zespół czynników, które budują kluczową relację zwrotną z potencjalnymi odbiorcami/konsumentami kontentu; należy tu wymienić:

C.1) właściwe badania oczekiwań odbiorców (nowoczesne metody badań interaktywnych);

C.2) obiektywny poziom cywilizacyjno-kulturowy populacji, grupy - ogólny poziom intelektualny (wykształcenie) społeczeństwa;

C.3) otwartość na zmiany/nowości programowe i technologiczne;

C.4) doinformowanie grupy o zmianach i planach, strategii stacji, stopień identyfikacji odbiorców, budowanie obrazu „mojej stacji”.

Wcześniej jednak, podczas przystępowania do badania determinantów jakości w mediach publicznych, istotne wyzwanie stanowiło prawidłowe ustalenie 
deskryptorów w praktyce wyznaczających obszar powstawania jakości w ujęciu ogólnym. Zastosowano tu metodę kluczowych czynników sukcesu $\left(\mathrm{KCS}^{8}\right)$, czyli takich, które definiują cele i strategię ergo zarządzanie strategiczne (Gierszewska, Romanowska, 2003, s. 17-18). Według tych kryteriów zdecydowano się prześledzić proces powstawania „jakości produktów medialnych”. Przez krzyżowe ujęcie kryteriów zastosowano metodę, która pozwala kompleksowo zbadać i ocenić przedsiębiorstwo (Bieniok i in., 1999). W ślad za tym z szerokiego zestawu wytypowano 12 obszarów strategicznych, najbardziej istotnych i determinujących sukces firmy, warunkujących system zarządzania i ekonomiki. Przedstawiono je w tabeli 1.

\section{Tabela 1. Kluczowe czynniki sukcesu determinujące sukces firmy}

\begin{tabular}{|c|c|}
\hline $\begin{array}{l}\text { KATEGORIE obszarów } \\
\text { w przedsiębiorstwie }\end{array}$ & $\begin{array}{l}\text { ODPOWIEDNKI W MEDIACH } \\
\text { mające istotny wpływ na jakość }\end{array}$ \\
\hline 1) Ogólne relacje z otoczeniem & $\begin{array}{l}\text { Udział w życiu społeczności (na swoim poziomie) przez } \\
\text { relacjonowanie zdarzeń, pomoc w różnych akcjach społecz- } \\
\text { nych, zbiórkach, szukanie zaginionych, ostrzeganie w razie } \\
\text { kryzysu; } 1 \text {. }\end{array}$ \\
\hline $\begin{array}{l}\text { 2) Technika, technologia i organizacja } \\
\text { produkcji }\end{array}$ & $\begin{array}{l}\text { Nowoczesne technologie HD, digitalizacja procesów pro- } \\
\text { dukcyjnych i nadawczych, tok produkcji; } 1 \text {. }\end{array}$ \\
\hline 3) Strategia rozwoju produktu & $\begin{array}{l}\text { Wizja programowa stacji i development poszczególnych } \\
\text { audycji; } 1 .\end{array}$ \\
\hline 4) Strategia i dystrybucja wyrobów & $\begin{array}{l}\text { Określenie grupy docelowej dla danej audycji i określenie } \\
\text { kanałów dystrybucji; } 1 .\end{array}$ \\
\hline 5) Strategia promocji i reklamy & $\begin{array}{l}\text { Sposoby dotarcia z własnym przekazem handlowym, dy- } \\
\text { wersyfikacja mediów; } 1 \text {. }\end{array}$ \\
\hline 6) Strategia cen & $\begin{array}{l}\text { Pozyskiwanie dobrych dochodów z reklam przez umiejęt- } \\
\text { ności negocjacyjne i rabatowe wobec zleceniodawców; } 1 \text {. }\end{array}$ \\
\hline 7) Planowanie & $\begin{array}{l}\text { Szacowanie poziomu dochodów względem zamierzeń } \\
\text { programowych w długich okresach; } 1 \text {. }\end{array}$ \\
\hline 8) Gospodarka czynnikiem ludzkim & Kompetencje redaktorów i producentów; 1 . \\
\hline 9) Gospodarka majątkiem trwałym & Optymalizacja użytkowania obiektów; 0,5. \\
\hline 10) Gospodarka materiałowa & $\begin{array}{l}\text { Magazynowanie środków inscenizacyjnych: scenografii, } \\
\text { rekwizytów, kostiumów itp.; 0,5. }\end{array}$ \\
\hline
\end{tabular}

8 Kluczowe czynniki sukcesu (KCS) to najważniejsze cechy organizacji, mające na względzie opisanie strategii i decydujące o przewadze konkurencyjnej i możliwościach rozwoju. 


\begin{tabular}{|l|l|}
\hline $\begin{array}{l}\text { 11) Endogeniczne wyznaczniki proce- } \\
\text { su zarządzania }\end{array}$ & $\begin{array}{l}\text { Akumulacja wiedzy naukowo-technicznej i kapitału ludz- } \\
\text { kiego, decyzje konsumentów i producentów postępujących } \\
\text { zawsze racjonalnie, przy jednoczesnej alokacji kapitału } \\
\text { przez państwo; } 1 .\end{array}$ \\
\hline 12) Wyniki, koszty i finanse & $\begin{array}{l}\text { Dbałość o równowagę między kosztami a przychodami } \\
\text { organizacji medialnej; 1. }\end{array}$ \\
\hline
\end{tabular}

Zastosowane wagi: $0,05,1$

Źródło: opracowanie własne na podstawie: Bieniok i in., 1999.

Według wybranych kluczowych kategorii zawartych w tabeli 1 można zaprojektować zestawienie na zasadzie macierzy, a także modelować przyjęte rozwiązanie trójkąta sił jakości.

W utworzeniu i uzupełnieniu tabeli o kolumnę „odpowiedniki w mediach” chodziło o wskazanie, które z czynników z obszaru ekonomiki i zarządzania będą brane pod uwagę jako istotne w tworzeniu specyficznej ankiety dotyczącej mediów. Jest to zgodne z teorią bilansu zasobów i zasadą „20-80” (Gierszewska, Romanowska, 2003, s. 162-163).

W mediach, w tym ujęciu, najważniejsze są punkty: $2,3,4,5,7,8,11,12$. W odniesieniu do pozostałych czynników przyjęto, że choć są istotne, nie biorą równorzędnego udziału w procesie tworzenia jakości programów i audycji. Z punktu widzenia realizacji strategii przedsiębiorstwa, zwłaszcza mediów publicznych, istotna jest szczególna polityka jakości, a w konsekwencji zarządzanie jakością treści medialnych. W tym budowanie relacji z klientem, czyli odbiorcą produktu, a szczególnie przekazu nadawcy medialnego. W związku z niejednoznacznym pojęciem jakości w mediach i brakiem innego (jak w ustawie o radiofonii i telewizji) jej określenie powinno się stać podstawowym zadaniem każdego przedsiębiorstwa medialnego, które chce panować nad tym elementem swojej oferty. Oglądając, odbiorca płaci i „akceptuje proponowaną mu jakość”. Podobnie prawdziwe jest twierdzenie, że jakość buduje wartość użytkową. W przypadku mediów jednak program nie ma jedynie tak rozumianej wartości utylitarnej, ale także kulturową, etyczną, duchową, edukacyjną i estetyczną.

Gdyby ludzie chcieli otrzymywać w mediach rzeczy dobre i wartościowe, to by je dostawali. Niestety problem polega na tym, że często nie uświadamiają sobie tego, co jest dobre i wartościowe $\mathrm{w}$ sensie obiektywnym, w sensie interesu publicznego czy w interesie szeroko rozumianej polityki państwa. I tu zaczyna się różnica między stacjami komercyjnymi a publicznymi. Stacje komercyjne nie są zobowiązane rozpoznawać tego rodzaju potrzeb [por. McQuail, 1994], dostarczają takie, jakich ludzie chcą, jakich oczekują, 
„Z niższej półki”. Natomiast stacje publiczne powinny je rozpoznać najpierw i te wyższe propagować .

Podobną myśl sformułował Jan Englert w odniesieniu do teatru: „(...) przeraża mnie przewaga ilości nad jakością, fakt, że ludzie nie aspirują do czegoś, co jest wyżej, że równają w dół” (Englert, 2020, s. 22).

W tym ujęciu widać, że dla zawartości przekazu medialnego być może najważniejsze są właśnie cechy pozautylitarne. Są to cechy gatunkowe audycji, estetyka, prezentacja, ekskluzywność itp.

Jednym z ważnych komponentów jest gust autorów i realizatorów audycji. To kategoria trudna do sparametryzowania, bo w swej istocie jest niemierzalna. W takim aspekcie ocena via trójkąt medialnych sił jakości zyskuje na znaczeniu.

Gust, smak, talent, kwalifikacje, kompetencje, profesjonalizm i szerokie horyzonty - to predylekcje do wypowiadania się przez prace artystyczne, filmowe czy literackie i wszelkie inne: muzyczne, plastyczne, baletowe, dziennikarskie. Po drugiej stronie jest odbiorca, który powinien mieć niezbędne kwantum wiedzy i dobrego smaku do umiejętnego odbioru dzieła artystycznego i medialnego. Oznacza to, że oprócz chęci i wolnego czasu do właściwego zrozumienia dzieła potrzebne są swoiste kwalifikacje. Treści nazbyt ambitne w stosunku do nieprzygotowanego widza, słuchacza, ogólnie - konsumenta, są adresowane w próżnię. Podobnie niewymagające, banalne - wobec dobrze przygotowanego. W sposób szczególny dotyczy to propozycji ambitnych, zwłaszcza w mediach publicznych, które dodatkowo stają przed trudnością takiego opracowania programu, by każdy mógł znaleźć treści interesujące dla siebie, dobrania odpowiednich godzin, autopromocji. Poza tym odbiór kultury i sztuki ma charakter dynamiczny, oparty na emocjach i zasadach uczenia się. Czym jest dzieło sztuki, trafnie zdefiniował Władysław Tatarkiewicz: „Dzieło sztuki jest odtworzeniem rzeczy bądź konstrukcją form, bądź wyrażaniem przeżyć, jednakże tylko takim odtworzeniem, taką konstrukcją, takim wyrazem, jakie są zdolne zachwycać bądź wzruszać, bądź wstrząsać” (Tatarkiewicz, 1986, s. 283). Józef Tischner zaś wypowiadał się o moralnych obowiązkach twórców sztuki (i dodam - także szeroko rozumianej kultury): „Są tacy, którzy sądzą, że sztuka jest ponad etyką. Nie odnoszą się do niej żadne zasady etyczne, ponieważ żyje ona ponad dobrem i złem. Kto tak sądzi, sam nie wie, jaką krzywdę wyrządza sztuce" (Tischner, 1981, s. 41-42).

9 Fragment wywiadu autora z Wojciechem A. Dróżdżem, przeprowadzonego na potrzeby artykułu. Wojciech A. Dróżdż - scenarzysta, pisarz, dramaturg, autor słuchowisk radiowych. 


\section{Rezultaty. Wyniki badań z 2021 roku}

Ankiety zebrane od respondentów posłużyły do: opracowania przedstawionych wyliczeń, histogramów, zbudowania modeli graficznych, które umożliwiają tworzenie numerycznych obliczeń macierzowych, oraz do wizualizacji wyników obliczeń w postaci rysunków statycznych i animacji komputerowej. Przeprowadzone badania, po ich wprowadzeniu do programu komputerowego, są widoczne na wielu grafikach, które ilustrują rozkład poszczególnych sił w obrębie trójkąta sił jakości. Jednak Na potrzeby tego artykułu, ze względu na ograniczone możliwości, przedstawiono tylko tabele sumaryczne.

Poniżej przedstawiono tabele 2 i 3, pokazujące średni rozkład punktów przyznanych w badaniu w 2021 roku w poszczególnych grupach, z rozbiciem na poszczególne czynniki. Celem jest porównanie dwóch badań wykonanych w odstępie sześciu lat. W związku z tym w dalszej części artykułu odniesiono się również do badań z 2015 roku.

Tabela 2. Badanie z 2021 roku sumarycznie w grupach

\begin{tabular}{|c|c|c|c|}
\hline \multicolumn{1}{|c|}{ Grupa czynników } & A & B & C \\
\hline Średnia pkt kategorii - studenci (S) & 3,38 & 3,95 & 3,79 \\
\hline Średnia pkt kategorii - profesjonaliści (P) & 3,19 & 4,19 & 3,75 \\
\hline
\end{tabular}

Źródło: badania własne autora.

Tabela 3. Badanie z 2021 roku z rozbiciem na czynniki w poszczególnych grupach

\begin{tabular}{|l||c|c|c|c||c|c|c|c||c|c|c|c|}
\hline Czynniki & A.1 & A.2 & A.3 & A.4 & B.1 & B.2 & B.3 & B.4 & C.1 & C.2 & C.3 & C.4 \\
\hline $\begin{array}{l}\text { Średnia pkt - } \\
\text { studenci }\end{array}$ & 3,14 & 3,33 & 4,15 & 2,90 & 4,23 & 4,16 & 3,54 & 3,85 & 4,30 & 3,58 & 3,99 & 3,29 \\
\hline $\begin{array}{l}\text { Średnia pkt } \\
\text { profesjona- } \\
\text { liści }\end{array}$ & 3,40 & 3,00 & 3,42 & 2,94 & 4,44 & 4,44 & 4,07 & 3,79 & 3,94 & 3,69 & 3,78 & 3,60 \\
\hline
\end{tabular}

Źródło: badania własne autora. 


\section{Dyskusja wyników}

Z badań można wysnuć wiele wniosków. Zestawienie pod kątem konfrontacji młodzieży z doświadczonymi pracownikami zawęziło wyniki, niemniej z klasyfikacji punktowej grup czynników A, B, C, zawartej w tabeli 2, dowiadujemy się, że:

- Dla jakości w mediach najważniejsi są: kreatywni pracownicy, wykształcona kadra z pomysłami (B.1, B.2), a cała reszta czynników stanowi uzupełnienie, które oczywiście w różnym stopniu sprzyja podnoszeniu jakości. Takie podejście widać w obu badaniach $(2015,2021)$. Na niemal identycznym poziomie ten czynnik wykazują zarówno profesjonaliści, jak i studenci. Niemniej większą wagę w całości grupy do tych czynników przyłożyli profesjonaliści (P-4,19vs S - 3,95) (zob. tabela 3).

- Drugim elementem w kształtowaniu jakości jest znajomość rynku odbiorcy, zarówno w 2015, jak i w 2021 roku, przy czym znaczenie nowoczesnych badań interaktywnych (C.1) i otwartość na zmiany (C.3) jest w dużo większym stopniu bliższa studentom w 2021 roku (S - 4,15 vs $\mathrm{P}-3,86)$.

- Należy zwrócić uwagę, że finansowanie jest dopiero na trzecim miejscu wśród czynników wpływających na rozumienie jakości. $Z$ doświadczenia wiemy, że niekiedy nie trzeba wielkich środków finansowych, by zaprojektować i wyprodukować coś atrakcyjnego czy nowatorskiego, często wystarczy wybitny pomysł, dobry menedżer/twórca i znajomość rynku. Choć oczywiście dostatek środków ułatwia planowanie produkcji, ale także zezwala na brak poszukiwań, na rutynę. W 2021 roku profesjonaliści traktują niemal na równi abonament (A.1, P - 3,40) z wpływami reklamowymi (A.3, P - 3,42), studenci zaś stawiają reklamę na pierwszym miejscu (A.3, S - 4,15), a na drugim przychody z tytułu obrotu prawami (A.2, S - 3,33). Wyraźnie niedoceniany jest przez nich abonament (A.1, S - 3,14).

W praktyce redakcyjnej, mówiąc o jakości we wszystkich gremiach, ostatecznie zawsze rozmawia się o finansach, a nie o ludziach, dlatego po przeanalizowaniu histogramów jakości grup badawczych pod kątem źródeł finansowania widać wyraźnie, że w praktyce w 2015 roku tylko opłaty abonamentowe miały prawdziwe znaczenie jako odniesienie na ścieżce kształtowania jakości (wyznaczanie standardów). W 2021 roku widzimy wyraźny spadek tej tendencji, abonament nie jest zauważany. Jednocześnie u studentów w 2021 roku widoczna jest tendencja docenienia wpływów $\mathrm{z}$ oferty $\mathrm{w}$ streamingu, co może być spowodowane wzrostem znaczenia na przykład VOD czy multiscreeningu u młodego pokolenia. Ciekawe natomiast jest to, że grupa profesjonalistów w 2015 roku nie wskazywała przychodów $\mathrm{z}$ reklamy i sponsoringu jako elementu mającego istotny wpływ w zakresie jakości, a obecnie, w 2021 roku, zauważalny jest trend zwyżkowy tego czynnika. Obydwa wykonane badania potwierdzają tezę, że im więcej jest środków finansowych z różnych źródeł, tym program może być lepszy i ciekawszy. Pod warunkiem jednak, że 
są zachowane zasady racjonalnego i prawidłowego zarządzania posiadanymi środkami finansowymi.

W zakresie znaczenia kwalifikacji kadry dla jakości w zasadzie obie grupy badawcze prezentują całkowitą zgodność w obydwu badaniach. Przy przyjętych dla obu badań zmiennych dotyczących jakości można zaobserwować, że najważniejszym czynnikiem mającym wpływ na program mediów są właśnie kwalifikacje kadry. Stąd też najbardziej uzasadnione wydaje się twierdzenie, że kwalifikacje kadry i jej doświadczenie rozumiane jako kapitał ludzki to elementy decydujące. Dlatego niedopuszczalne powinno być demontowanie latami wypracowywanego systemu redakcyjnego, błędem kierownictwa jest zwalnianie doświadczonych dziennikarzy i części twórców bez uzasadnionych merytorycznie powodów, a także rezygnowanie $\mathrm{z}$ relacji mistrz-uczeń czy sytuacji, kiedy niejasne stają się ścieżki karier w mediach publicznych. Wymienione elementy powinny bowiem stanowić o przewadze konkurencyjnej w zakresie jakości treści programowej, o standardach i kreatywności.

Różnice występujące między badanymi grupami w ocenie danych każdej kategorii są mniej istotne, choć daje się zauważyć, że największa rozbieżność między młodymi adeptami dziennikarstwa a profesjonalistami występuje w zakresie źródeł finansowania. Tendencja ta pogłębiła się w 2021 roku; zwłaszcza studenci średnio o 0,3 pkt mniej akcentują abonament, i prawie o 0,74 pkt wyżej oceniają wpływy z reklamy. Jest to efekt, który daje się wytłumaczyć obniżeniem kwot abonamentu pobieranego jako opłata za używanie odbiornika rtv (Nowelizacja ustawy o radiofonii i telewizji, 2018), przy jednoczesnym pojawieniu się nowych nośników odbioru, jak również archaicznością procedury, niechęcią społeczną, przy jednoczesnym braku rozumienia skomplikowanego systemu rekompensat, pożyczek itp., zaciemniającego obraz przychodów w mediach publicznych (Rogowski, 2018).

Niedostrzeganie przez studentów znaczenia abonamentu jako istotnego źródła finansowania mediów publicznych już w 2015 roku i pogłębienie tego trendu w roku 2021. może być jednak sygnałem pokazującym z jednej strony nierozumienie, $z$ drugiej nieprzydatność jego funkcji w systemie. W uproszczeniu - młode pokolenie uważa, że pieniądze powinny być na produkcję programów, bez stawiania warunków, jak i na co będą wydawane. Oznaczałoby to niskie rozumienie przesłania o misji mediów publicznych, a koncentrowanie się na przesłankach pragmatycznych, roli profesjonalnej kadry, marketingu i dywersyfikacji źródeł przychodów. Dalej idącym wnioskiem jest stwierdzenie o niższych oczekiwaniach w odniesieniu do zawartości programowej, jak również to, że w ostatnim okresie (chociażby pięciu lat) następowało stałe obniżanie standardów jakościowych (misyjnych), postępowała komercjalizacja przyjmowana przez nowe pokolenie za normę (nieznajomość standardów czy kanonu mediów publicznych), co - być może między innymi - jest skutkiem zmiany kanonów i wychowania odbiorców przez nowe media, jak również przez media komercyjne stricte w obrębie radia i telewizji. 


\section{Wnioski i podsumowanie}

Na podstawie rozważań teoretycznych, jak i szerokiego badania literatury pierwsza część hipotezy znajduje potwierdzenie, to jest jakość stanowi istotny czynnik wpływający na realizację strategii publicznej organizacji medialnej. Tym samym, jak twierdzi Tadeusz Kotarbiński, sprawność i skuteczność organizacji zależy od różnych czynników (Kotarbiński, 1970, s. 250).

Wyniki badań potwierdzają hipotezę, że zróżnicowane czynniki determinujące jakość w mediach (rtv) wpływają nierównomiernie na jej powstawanie; najważniejsze są kwalifikacje pracowników mediów (B), następnie znajomość rynku odbiorcy (C) i finasowanie (A). Zjawiska wokół i na rynku mediów mają charakter dynamiczny, wielowarstwowy, co rzutuje na postrzeganie treści przez odbiorców. Ich postawy, także wyrażone przez ankiety, są tego odbiciem. Na naszych oczach stopniowo znika tak zwany abonament - to źle i dobrze. Źle, bo przestaje się kojarzyć $\mathrm{z}$ finansowaniem misji, która była arką treści słusznych i kwalifikowanej jakości, co gorsze - zwalnia nadawców publicznych od odpowiedzialności za treść przy jednoczesnym braku zaufania części odbiorców. Dobrze, bo skłania do redefinicji sposobu finasowania i zadań mediów publicznych, które na naszych oczach tracą swój powab i status czołowego nadawcy w państwie, pierwszego ogniwa w prawdziwym informowaniu i publicystyce czy wyznaczającego wysokie standardy artystyczne. Dzieje się tak, ponieważ media publiczne zrezygnowały z obiektywizmu na rzecz instrumentalnej propagandy, a wysoki poziom artystyczny zastąpiły szmirą. Badanie tych zjawisk z jednej strony jest konieczne, z drugiej jednak - trzeba pamiętać, że horyzontalny układ nowych mediów elektronicznych powoduje zalew informacji i inercję odbiorców (Rogowski, 2020), może sprzyjać kształtowaniu postaw akceptacji takiego stanu, a zwłaszcza ambiwalencji wobec omawianych zjawisk.

Jednocześnie pojawia się konkluzja, że konieczne jest traktowanie zagadnień jakości jako ważnego celu, narzędzia i przedmiotu w ramach projektowanych strategii w mediach.

Model trójkąta sił jakości został wykorzystany do badania determinantów jakości w mediach publicznych, de facto jest instrumentem uniwersalnym, pozwalającym badać różne organizacje medialne i zjawiska na rynku mediów przez różną, odpowiednio dopasowaną konfigurację deskryptorów.

\section{Bibliografia}

Albaran A. (2016). The Media Economy. $2^{\text {nd }}$ ed. London: Routledge.

Arystoteles (2006). Polityka. Księga VIII, t. 4. W: L.M. Piotrowicz, M. Szymański (red.). Dzieła wszystkie. Przeł. L.M. Piotrowicz. Warszawa: Wydawnictwo Naukowe PWN.

Bauman Z. (1998). Globalization: The Human Cosequences. Cambridge: Polity Press. 
Bieniok H., Ingram M., Marek J. (1999). Kompleksowa metoda diagnozowania systemu zarzqdzania przedsiębiorstwem. Katowice: Wydawnictwo Uczelniane Akademii Ekonomicznej.

Cardona P., Rey C. (2013). Zarządzanie poprzez misję. Przeł. M. Justyna. Kraków: Oficyna a Wolters Kluwer Business.

Cyfrowy Polsat. Misja, wizja i strategia (2020). Pobrane z: https://grupapolsat.pl/pl/nas/misja-wizja-strategia (dostęp: 8.04.2021).

Drummond H. (1988). W pogoni za jakością. Przeł. N. Pikielna, Z. Zielińska. Warszawa: ABC. Englert J. (2020). Jan Englert w rozmowie z Piotrem Zarembą. Nawet ja zaczałem ogląać Netflixa. „Rzeczypospolita Plus Minus”, 26-27 września.

Frąś J. (2013). Kompleksowe zarządzanie jakością w logistyce. Radom: Wydawnictwo Naukowe Instytutu Technologii Eksploatacji - Państwowego Instytutu Badawczego.

Gierszewska G., Romanowska M. (2003). Analiza strategiczna przedsiębiorstwa. Warszawa: Polskie Wydawnictwo Ekonomiczne.

Glaser B., Strauss A. (2009). The Discovery of Grounded Theory: Strategies for Qualitative Research. London: Transaction Publishers.

Graham A., Davis G. (1997). Broadcasting, Society and Policy in the Multimedia Age. Luton: University of Luton Press.

Hamrol A., Mantura W. (2002). Zarządzanie jakością. Teoria i praktyka. Warszawa-Poznań: Wydawnictwo Naukowe PWN.

Henry J., Johnson G., Newton J. (1993). Strategic Thinking. Chichester: John Wiley \& Sons.

Jakubowicz K. (2007). Media publiczne. Początek końca czy nowy początek. Warszawa: Wydawnictwa Akademickie i Profesjonalne.

Jakubowicz K. (2013). Media a demokracja w XXI wieku. Poszukiwanie nowych modeli. Warszawa: Wydawnictwo Poltext.

Kosiorowski Z. (2014). Zarządzanie tożsamościa jednoosobowej spótki skarbu państwa w sektorze mediów elektronicznych. „Zeszyty Naukowe Zachodniopomorskiej Szkoły Biznesu Firma i Rynek", 1, s. 72-85.

Kotarbiński T. (1970). Studia z zakresu filozofii, etyki i nauk społecznych. Wrocław [etc.]: Zakład Narodowy im. Ossolińskich.

Kotarbiński T. (2019). Traktat o dobrej robocie. Łódź: Wydawnictwo Uniwersytetu Łódzkiego.

Kłeczek R., Kowal W., Woźniczka J. (2001). Strategiczne planowanie marketingowe. Warszawa: Polskie Wydawnictwo Ekonomiczne.

Lisiński M., Szarucki M. (2020). Metody badawcze w naukach o zarządzaniu i jakości. Polskie Wydawnictwo Ekonomiczne.

McQuail D. (1994). Mass Communication Theory: An Introduction. London: Sage Publications.

Nierenberg B. (2011). Zarządzanie publicznym przedsiębiorstwem medialnym. Kraków: Wydawnictwo Attyka.

Rogowski S. (2016). Współczesna publiczna radiofonia regionalna $w$ Polsce; aspekty programowe, finansowe i regulacyjne. Rozprawa doktorska. Instytut Dziennikarstwa, Uniwersytet Warszawski.

Rogowski S. (2018). Universal Audiovisual Contribution - Possibility or Necessity? W: B. Nierenberg [i in.] (red. nauk.). Media Economics. Economic Issues in the Media: Theory and Practice. Warszawa: Wydawnictwo Naukowe PWN.

Rogowski S. (2020). Dystrybucja utworów audiowizualnych w społeczeństwie kontentowym. W: S. Rogowski, A. Wróblewska (red.). Dystrybucja filmowa. Od kina do streamingu. Warszawa: Wydawnictwo Naukowe Semper.

Skowron-Grabowska B. (2021). Łańcuchy wartości w zarządzaniu organizacjami. Wyzwania innowacyjno-kryzysowe. Warszawa: Polskie Wydawnictwo Ekonomiczne. 
Sudoł S. (1992). Przesłanki strategii przedsiębiorstwa w zakresie jakości. W: T. Borys, S. Sudoł (red.). Jakość wyrobów. Strategia i sterowanie w przedsiębiorstwie przemysłowym. Kraków: Pracowania Pomocy Naukowo-Dydaktycznych Akademii Ekonomicznej.

Sułkowski Ł. (2012). Epistemologia i metodologia zarzadzania. Warszawa: Polskie Wydawnictwo Ekonomiczne.

Tatarkiewicz W. (1986). O filozofii i sztuce. Warszawa: Państwowe Wydawnictwo Naukowe.

Tazowski L. (2019). Zmiany prawa medialnego 2015-2018. W: J. Dworak, J. Weksler (red.). Raport: Media publiczne 2015-2019. Studium upadku i co dalej? Warszawa: Instytut Bronisława Komorowskiego.

Tischner J. (1981). Etyka solidarności. Kraków: Znak.

Towse R. (2011). Ekonomia kultury. Kompendium. Przeł. H. Dębowski, K.L. Pogorzelski, Ł.M. Skrok. Warszawa: Narodowe Centrum Kultury.

Wolny-Zmorzyński K., Kaliszewski A., Furman W. (2006). Gatunki dziennikarskie. Teoria, praktyka, język. Warszawa: Wydawnictwa Akademickie i Profesjonalne.

\section{Akty prawne}

Ustawa z dnia 29 grudnia 1992 r. o radiofonii i telewizji. Dz.U. 1993 nr 7 poz. 34, t.j. Dz.U. 2020 poz. 805.

Ustawa z dnia 21 kwietnia 2005 r. o opłatach abonamentowych. Dz.U. 2005 nr 85 poz. 728, t.j. Dz.U. 2020 poz. 1689 ze zm.

Ustawa z dnia 20 lipca 2018 r. o zmianie ustawy o radiofonii i telewizji oraz ustawy o opłatach abonamentowych. Dz.U. 2018 poz. 1717. 
